\title{
Reading a bureaucratic career backwards: how did Hüseyin Hilmi Pasha become the Inspector- General of Rumelia?
}

\section{Sena Hatip Dinçyürek}

To cite this article: Sena Hatip Dinçyürek (2017) Reading a bureaucratic career backwards: how did Hüseyin Hilmi Pasha become the Inspector-General of Rumelia?, Middle Eastern Studies, 53:3, 386-405, DOI: $10.1080 / 00263206.2016 .1241245$

To link to this article: https://doi.org/10.1080/00263206.2016.1241245

曲 Published online: 03 Nov 2016.

Submit your article to this journal $\pi$

Џ Article views: 138

Q View related articles $\widetilde{ }$

View Crossmark data $\asymp$ 


\title{
Reading a bureaucratic career backwards: how did Hüseyin Hilmi Pasha become the Inspector-General of Rumelia?
}

\author{
Sena Hatip Dinçyürek \\ Department of History, Bilkent University, Ankara, Turkey
}

In the final days of November 1902, as a result of the ongoing European pressure for the implementation of reforms in Ottoman Macedonia, Sultan Abdülhamid II issued a decree called 'the Ordinance on the Rumelian Provinces' (Rumeli Vilâyâtı Hakkında Talimâtnâme). This document was a milestone for the Macedonian Question and brought with it a number of institutions, the most important of which was the General Inspectorate of Rumelia (Vilâyât-ı Selâse Umûm Müfettişliği). Hüseyin Hilmi Pasha was appointed as the inspector general (müfettiş-i umûmi), and all the administrative units of the Three Provinces (VilâyâtI Selâse) - Salonica, Manastır (Bitola) and Kosovo - were entrusted to his supervision. ${ }^{1}$

There was indeed something peculiar in the appointment of Hüseyin Hilmi Pasha to this post. His position can be described as an extraordinary governor above the Three Provinces, with an overriding authority over the provincial governors (vâlis). That is why his appointment to the inspectorate of Rumelia immediately raised certain rumours and questions among his contemporaries. Fazlı Necip, a journalist and the publisher of the daily Asır, was one of them. He wrote:

We Macedonians were following all these developments with a nervous excitement. The Istanbul papers could not speak of this issue. However, all through Macedonia the news of the enterprise was learned of in detail from foreign papers. It was at this time that one day we received the news of Hüseyin Hilmi Pasha's appointment as Inspector General of the Rumelian Provinces. We asked each other, 'Who is this Hüseyin Pasha?' He was not a famed dignitary. He had never been to Rumelia. People talked about it everywhere for days in order to comprehend the characteristics of this inspector who was to rule the great territory of Rumelia as a semi-autonomous prince. ${ }^{2}$

The General Inspectorate of Rumelia was not the highest state position that Hüseyin Hilmi Pasha ever reached. Later in his career, he not only served as Minister of the Interior (1908-09) and Minister of Justice (1912), but he also held the seal of the grand vizierate twice (1909 and 1910). However, once the pasha had achieved a position as high as the inspectorate, such high-ranking subsequent appointments can be seen as not so surprising. As such, this article aims primarily to find an answer to the question raised by Fazlı Necip, and, second, to reconstruct and understand the path that led Hüseyin Hilmi to one of the most significant positions to be specifically created under the special conditions of the empire in the early years of the twentieth century. 
This article is therefore a biographical study that examines Hüseyin Hilmi Pasha as a prominent statesman with the aim of discovering whether his example can be portrayed as a good example of the Hamidian way of governing. It is within this context that he made a very fortunate start to his career in government service, after which his professional career moulded him into an expert in 'crisis management'. He served in different parts of the empire that had similar problems. At first glance, it may seem bizarre to see a governor who had always been deployed in the eastern provinces - particularly in southern Anatolia, Syria and Yemen - being appointed to Ottoman Macedonia at a time of serious political and diplomatic crisis. However, a deeper analysis of his career path will help us understand the logic behind the rise of this Ottoman statesman during the reign of Abdülhamid II.

In the mid-1870s, when Hüseyin Hilmi's bureaucratic career began, most high officials were products of the Tanzimat system, and quite a few were graduates of 'modern' schools. However, this was not the case for Hüseyin Hilmi, who came from a humble background. In a partial autobiographical account, he wrote that he was born on a Thursday on 13 Rebiülevvel 1273 (11 November 1856) in Sarlıca, a village on the island of Midilli (Lesbos). He gives details concerning his family and identifies himself as a Muslim on both the paternal and the maternal side. His paternal grandfather had previously migrated to Midilli from Kütahya, while his maternal grandfather had been a palace servant. ${ }^{3}$ As he was often 'blamed' for being of Greek origin, which was perhaps a general attitude held by the wider public toward those born on the Aegean islands, it is not surprising to see that he wanted to elucidate his family roots. He first attended the local sibyan mektebi (primary school) and then received an education in a madrasa in Midilli. He obtained a firstclass diploma as an attorney (dava vekili) in 1882. ${ }^{4}$ According to his Sicill-i Ahvâl record (official personal record), he could read Turkish, Arabic and French, and was familiar with Greek as well. Hüseyin Hilmi 'Efendi' ${ }^{5}$ began his professional training (mülâzemet, or internship) for civil officialdom in the secretariat of Midilli (Midilli Tahrirat Kalemi) in $1874 .^{6}$ As he was an Ottoman civil servant or bureaucrat not from a well-known family, it is not always possible to obtain detailed information or find reliable sources on his early years. In the case of Hüseyin Hilmi, we are extremely lucky to have written primary documents from the pen of Namık Kemal, one of the most renowned men of letters of the time in the empire. ${ }^{7}$

Namık Kemal was 'kindly distanced' - not to say exiled - from Istanbul by Abdülhamid II on 19 July 1877, and he headed to Midilli for his 'mandatory residence' (ikâmete memûr) due to his political stance. ${ }^{8}$ In fact, two and a half years later, Namık Kemal was to become the mutasarrif or district governor of the island. ${ }^{9}$ It would not be wrong to presume that this was around the time when young Hüseyin Hilmi met Namık Kemal, a critical acquaintance that was to change his entire life.

Many sources refer to Hüseyin Hilmi as Namık Kemal's personal scribe during the latter's governorate in Midilli. However, his official record reveals that by the time Namık Kemal arrived on the island (late July/early August 1877), Hilmi Efendi had already been in state service for two years, serving as the chief scribe in the Tahrîr-i Emlâk Kalemi (Land Registry Office) since June $1876 .{ }^{10}$ Nevertheless, it is very likely that Hilmi Efendi served Namık Kemal as a de facto personal clerk as well. ${ }^{11}$ The name 'Hüseyin Hilmi' would appear 


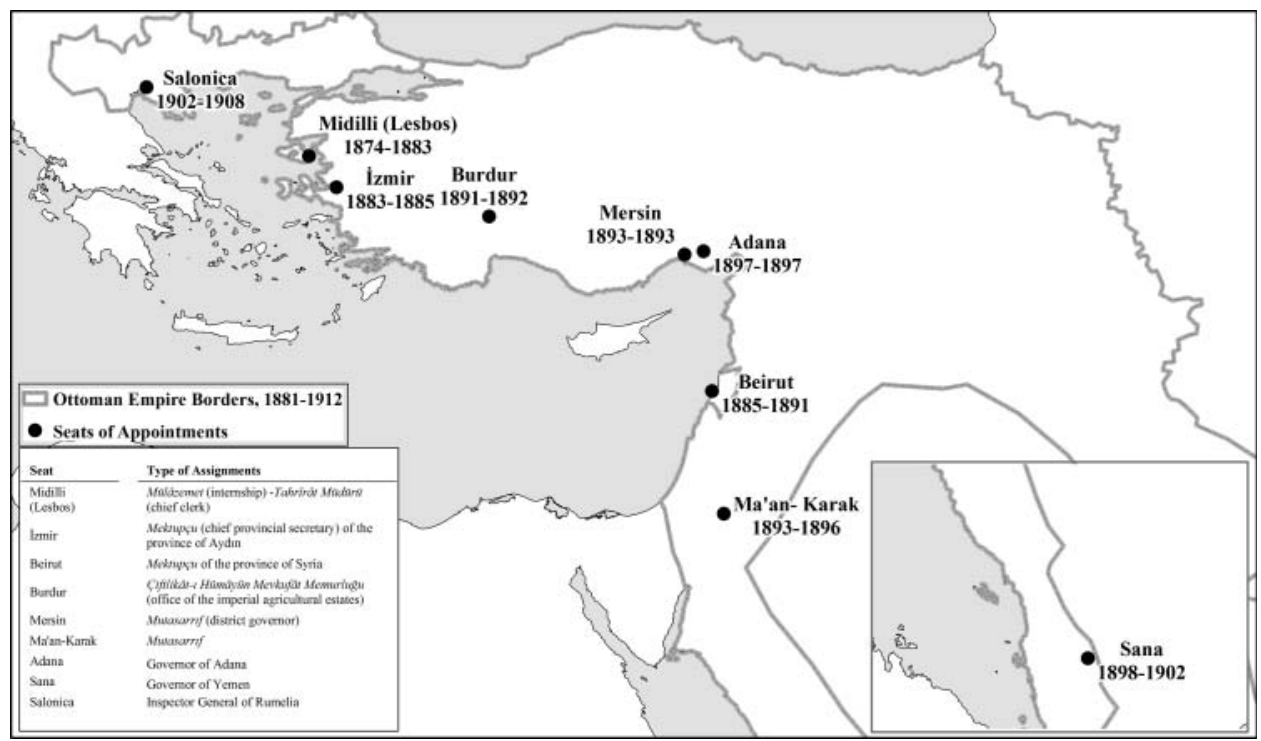

Figure 1. Map of Hüseyin Hilmi Pasha's career up to the General Inspectorate of Rumelia.

in Namık Kemal's letters to third parties from 1878 onwards. ${ }^{12}$ A recent publication by Ali Akyıldız and Azmi Özcan has revealed a closer and deeper relationship between these two men. ${ }^{13}$ Namık Kemal's hitherto unpublished personal letters, of which a great majority are addressed to Hüseyin Hilmi, shed significant light on their intimacy. Moreover, an examination of their relationship shows that it fits perfectly into the concept as well as the common practice of intisâb. ${ }^{14}$ It was this door opened before Hüseyin Hilmi that enabled him to build a career which would finally lead him to the grand vizierate.

On 9 May 1881, Hüseyin Hilmi Efendi became Midilli Tahrîrât Müdürü (chief clerk of official correspondences). Namık Kemal had been the mutasarrif since December 1879; hence, this promotion must have been his initiative. ${ }^{15}$ Hüseyin Hilmi served in this position until his appointment to the province of Aydın on 12 August $1883 .{ }^{16}$ The last four years of his service under Namık Kemal appears to have laid the foundations of Hüseyin Hilmi's career as a bureaucrat. Hüseyin Hilmi - together with another young official, Tevfik Bey - became Namık Kemal's indispensable companions. In addition to his other duties, he played the role of a courier for his superior's letters and packages between the island and Istanbul. ${ }^{17}$ This must have been a great opportunity for him to get to know the Ottoman capital and its circles.

During the years that Hüseyin Hilmi served Namık Kemal, he must have learned quite a deal from him in terms of bureaucratic manners and correspondence, and in any case it would be a mistake to presume that a public intellectual and important literary figure like Namık Kemal, who influenced generations of Ottomans, had no intellectual impact on Hüseyin Hilmi. In a letter to Ziya Pasha, Namık Kemal added a note at the end explaining, in a sarcastic tone, how his clerks - probably referring to Hüseyin Hilmi - valued his writings and were keen to make fair copies, not even letting him write down his own letters. ${ }^{18}$ At the same time, Namık Kemal did seem rather fond of his young companions on the island. In 1881, hearing rumours that Tevfik and Hüseyin Hilmi would be replaced, he did 
not refrain from threatening to resign from his post should that happen. ${ }^{19}$ In the end, the course of events showed that Namık Kemal would not avoid doing whatever was necessary to open doors before Hüseyin Hilmi and attempt to ensure his promotion.

In May 1883, Namık Kemal wrote to the Ministry of the Interior and elaborately praised Hüseyin Hilmi Efendi as he nominated him for the vilâyet mektupçuluğu (chief provincial secretary) of the Province of the Islands of the Archipelago (Vilâyet-i Cezair-i Bahr-i Sefid). ${ }^{20}$ Two months later, on 14 July 1883, Namık Kemal penned another 'reference letter' for his protégé, this time addressed to the governor Naşid Pasha, who had recently been transferred from the governorship of the Archipelago to Aydın. In his carefully worded letter, Namık Kemal asked for Hüseyin Hilmi Efendi's promotion. He articulated the fact that relinquishing Hüseyin Hilmi's company would be a great loss on his part; however, he would never hinder, for his own comfort, the bright future (feyz) that awaited Hüseyin Hilmi. He praised his disciple's efforts at self-improvement, and particularly stressed how he overcame the handicaps of his childhood environment. ${ }^{21}$ When Namık Kemal later received the telegram informing him of the imperial edict for the appointment of Hüseyin Hilmi Efendi as chief provincial secretary of Aydın, his message of congratulations to Hilmi adopted a fatherly tone: 'I congratulate your tenure, on the condition that it is the beginning of your prosperity'. ${ }^{22}$ The appointment to the province of Aydın was a huge step forward in Hüseyin Hilmi's bureaucratic career. On 12 August 1883, Hüseyin Hilmi left his home and the island for the first time to embrace the larger empire.

Izmir, a cosmopolitan city with a population of around 200,000, was the provincial capital of the province of Aydın. It was an important port city not only for the Ottoman Empire, but also for the eastern Mediterranean as a whole: a rapidly growing commercial centre that connected Anatolia with overseas trade ports. ${ }^{23}$ As compared to Midilli, Hüseyin Hilmi Efendi now found himself in a much more challenging environment. The governor's office must have been in constant contact with many European representatives who resided in Izmir. It would not therefore be a mistake to consider these two years as Hüseyin Hilmi's first encounter with the Europeans. Serving under the governor of Aydın, Nașid Pasha, under such conditions at such an early phase of his career must have offered him new opportunities.

Hüseyin Hilmi's new patron, Naşid Pasha, was an experienced governor; he was also famous for his merciless solution to the ongoing problem of banditry in the mountains of Izmir. ${ }^{24}$ During his post in Aydın province from 1883 to 1885 , Hüseyin Hilmi climbed the first ranks of the bureaucracy and received his first state order of the fourth degree (NişanI Âl-i Osman) for his services in assisting earthquake victims in Çeşme in $1884 .{ }^{25}$ His years in Izmir also coincided with the consolidation of Hamidian rule throughout Empire. It was already Abdülhamid II's seventh year on the throne, and Hüseyin Hilmi was becoming a part of this absolutist order as a Hamidian bureaucrat. ${ }^{26}$

It was also in Izmir that Hüseyin Hilmi started a family. Some information on his personal life can be found, again, in Namık Kemal's letters, from which we understand that Hüseyin Hilmi married Fatma Zehra Hanım, the daughter of Abdi Bey, a member of the local council of Midilli. ${ }^{27}$ Hüseyin Hilmi and Namık Kemal continued their correspondence throughout the former's years in Izmir, and Namık Kemal continued to contribute to his 
protégé's progress through his letters. He openly supported his promotion in the state service and made it clear that he expected more from him. One side of their 'written dialogue' can be traced for eight years, since Namık Kemal's letters are preserved among Hüseyin Hilmi's personal papers. These letters clearly show how Namık Kemal remained Hüseyin Hilmi's mentor till the end of the former's life.

Nașid Pasha was appointed governor of Syria in 1885 and sought to take Hüseyin Hilmi with him. Namık Kemal recommended Hüseyin Hilmi to follow Nașid Pasha, while also openly regretting the fact that Hüseyin Hilmi did not openly ask for a mutasarriflık himself. Apparently this was a subject that was actually on the table, at least according to their correspondence. Namık Kemal believed that a change of post was not likely once Hüseyin Hilmi began to serve as mektubcu in Syria, since the governor would not want to lose his companion. ${ }^{28}$ Nonetheless, later evidence reveals that Namık Kemal was proven wrong in his worries: some years later, Naşid Pasha did in fact nominate his subordinate for the position of mutasarrıf of Beirut. ${ }^{29}$

Before this, however, Hüseyin Hilmi Efendi was first appointed as chief provincial secretary of Syria (Suriye Vilâyet Mektubcusu) on 16 September 1885, a position in which he remained for almost six years. ${ }^{30}$ After a while, he apparently wished to change his post, at which point Namık Kemal again stepped in and suggested he abstain from such an attempt, perhaps thinking it was not the right time to make such a demand. ${ }^{31}$ Instead, on 25 November 1885, Hüseyin Hilmi was granted a prestigious title as an addition to his current post: 'honorary member to the commission for the imperial estates' (Arazi-i Seniyye Komisyonu Fahri Azalığı). Records show that in September 1887 Hüseyin Hilmi Efendi was on leave for a month and went to Istanbul. ${ }^{32}$ The following month, on 6 October 1887, he received another state order, this time a Nişan-ı Âl-i Osmani of the third degree. ${ }^{33} \mathrm{He}$ also received the Order of the Crown of Italy (Ordine della Corona d'Italia) in the spring of 1887, while still serving as the chief provincial secretary of Syria. ${ }^{34}$ After the death of Nașid Pasha in 1888, Hüseyin Hilmi continued in this post for almost three more years. ${ }^{35}$

1888 must have been a difficult year for Hüseyin Hilmi. On 2 December, Namık Kemal passed away on Chios, where he had been serving as mutasarrif since the previous year. The only letter written by Hüseyin Hilmi to Namık Kemal that is extant today is the very last one. ${ }^{36}$ According to F. A. Tansel, the following sentence was written at the bottom of this letter with someone else's handwriting: "This is the letter that he [Namık Kemal] read but was unable to understand two hours before his death. ${ }^{37}$ Hüseyin Hilmi had lost his mentor of many years, and with the termination of Namık Kemal's dispatches, we are also deprived of a precious source.

Hüseyin Hilmi Efendi resigned from his post in Syria on 14 February 1891 and was appointed to Çiftlikat-ı Hümayun Mevkufat Memurluğu (Office of the Imperial Agricultural Estates) in Burdur on 26 April 1891. ${ }^{38}$ A year later, while serving in Burdur, Hüseyin Hilmi received a dispatch from the Ministry of Finance informing him that he was under consideration for the Administration of the Imperial Estates (Arazi-i Seniyye Idare Müdürlüğ̈̈) in Baghdad, as well as for membership in the Commission for the Imperial Estates (Arazi-i Seniyye Komisyonu Azalığı). The reason for these potential appointments was primarily the fact that his duty at Burdur was not to last long, owing to fiscal difficulties. ${ }^{39}$ While expressing his gratitude in his response, however, Hüseyin Hilmi asked not to be appointed to these positions, putting forward as an excuse certain health issues, as well 
as the inadequacy of the salary. ${ }^{40}$ This was the first of many times throughout Hüseyin Hilmi's career that he would use his health as a justification for turning down a post.

On 10 December 1892, the governor of Adana, Abdülhalik Nasuhi, wrote a detailed dispatch to Yıldız Palace summarizing the state of affairs in Adana Province, with a special emphasis on the Armenians of the region. The district (sancak) of Sis was the seat of the Armenian Catholicos and had a sizeable Armenian population. Mersin, another important port city in Adana province, also had a delicate administrative status due to the numerous foreigners residing there, who were generally interested in the condition of the empire's Christian population. Local officials therefore needed to be in frequent contact with these Europeans. Under these circumstances, the governor asked for the replacement of mutasarrıf Fehim Pasha with Hüseyin Hilmi Efendi:

\begin{abstract}
With a significant number of subjects and foreign relations that deserve special attention, it is appropriate to deploy a servant to the mutasarrfflk of the sancak of Mersin, who, in addition to being loyal and astute, must also be intelligent and acquainted with foreign languages and transactions. [l therefore dare] to show the courage of asking permission of his imperial highness that the current mutasarrif, Fehim Pasha, be transferred to another suitable location and in his place be appointed [the former secretary of Syria Hüseyin Hilmi Efendi], who is known for his competence, loyalty and acquaintance with foreign affairs, and for his sufficient experience and knowledge of several languages, and who was also nominated for such an important mutasarriflik as that of Beirut. ${ }^{41}$
\end{abstract}

The expected order came on 11 January $1893 .{ }^{42}$ This appointment can be regarded as the first of many coming posts with a similar pattern: Hüseyin Hilmi was assigned to a critical place under fragile political conditions and had to struggle, as the government's representative, with numerous counterparts.

It is difficult to evaluate the level of his success in Mersin, since only two months after the appointment he was transferred to the sancak of Ma'an, again in the province of Syria. ${ }^{43}$ This appointment was to be the turning point in Hüseyin Hilmi's career, since his years in Ma'an coincided with "the establishment of a new administrative set up" ${ }^{44}$ in the region, therefore assuring his recognition by the sultan.

As Eugene L. Rogan has described it, Ma'an was a 'fortified oasis town on the pilgrimage route [to Mecca] ${ }^{\prime 4}{ }^{45}$ It was located on the trade route that started in the ports of Aqaba and Eyle on the Red Sea and headed to Amman and to Iraq. ${ }^{46}$ It was an important stop for traditional Hajj caravans ${ }^{47}$ and was to become an important station on the Hijaz railroad two decades later. This region was Aqaba's hinterland and was home to intertribal conflicts and blood feuds. It was a traditionally autonomous area which the central government was only interested in for its location on the pilgrimage route. However, in the late 1880s, the Hamidian regime started to pay closer attention to the area for two basic reasons: first, after the British occupation of Egypt in 1882, the region was considered vulnerable to regional British designs; and second, Abdülhamid II utilized Islam as a tool of solidarity among his subjects. ${ }^{48}$ On 18 August 1892, an imperial decree was issued to establish a mutassarriflı in Ma'an, and the governor of Damascus, Rauf Pasha, was assigned to make the necessary arrangements. The process was completed by March of the following year. ${ }^{49}$ Based on the fragility of the conditions in this new administrative unit, the governor made a formal request to the central government for authorization to 
select the mutasarrifs and kaimakams himself, which was an exception to the existing regulations. Rauf Pasha also asked that the administrative officials to be appointed to Ma'an be of the highest possible ranks on the payment and promotion scale. ${ }^{50}$ The central government seems to have responded positively to his request regarding rank and payment, as can be observed in the correspondence concerning the promotions of Hüseyin Hilmi, who was to become the first mutasarrif of Ma'an. ${ }^{51}$

After six months, the capital of the mutasarriflık was transferred from Ma'an to Karak as a result of requests by the locals as well as due to certain economic realities in the region. The transfer, however, was not a smooth process. In October 1893, Hüseyin Hilmi Efendi set off with a battalion of infantry and a squadron of cavalry as well as administrative and judicial personnel. Rogan narrates the subsequent events based on eyewitness accounts:

[T]he Ottoman force was greeted 'with rifle shots' and by 'huge stones rolled down from above". From these accounts it appears that the town was in a state of siege for the better part of a week, and that the new administration was only admitted after extensive negotiations were concluded and costly gifts exchanged. ${ }^{52}$

This was an arduous mission from beginning to end, as Hüseyin Hilmi was serving in an extremely difficult environment in both geographic and socio-political terms. His personal papers provide us with some clues regarding the issues with which he had to deal. For instance, in the fall of 1893, the Druzes of Hauran had rebelled against the Ottoman authorities and besieged the military barracks in the region. The siege continued for sixty hours, but, due to resistance by the Ottoman forces, the rebels were unable to enter. The governor of Syria and the commander of the 5th Army assigned Hüseyin Hilmi to the head of the commission that was to proceed to Hauran to peacefully end the siege and restore order in the region. According to Hüseyin Hilmi's report - dated 21 October 1893, right after his arrival in the city - he met with local sheiks and leaders and persuaded them to peacefully end the siege. This crisis was thus successfully overcome, and in the end the Druzes expressed their loyalty to the sultan. ${ }^{53}$ The ongoing conflict between the region's Arabs and Druzes was also an issue that the government had to resolve; in this, Hüseyin Hilmi played a mediatory role between the two parties, preventing the conflict from escalating. ${ }^{54}$.

Apart from such issues, Hüseyin Hilmi also had concerns about the presence of British missionaries in the region and struggled against their involvement in local affairs. ${ }^{55}$ In order to overcome these obstacles, he petitioned the sultan and the provincial government to improve the regional infrastructure, recommending that telegraph lines be built between the Syrian provinces and the $\mathrm{Hijaz}^{56}$ and that a steamboat be employed to expedite transportation to the region. ${ }^{57}$ Abdurrahman Şeref was one of the contemporaries who evaluated Hüseyin Hilmi's achievements in Ma'an-Karak:

He stayed in the aforementioned district [Ma'an] for almost four years and succeeded in putting under proper organization and the rule of law those places where the rule of government could not be thoroughly constituted before. ${ }^{58}$

It is rather significant that with the establishment of the new administrative structure in Ma'an-Karak region, Ottoman rule reached the southernmost part of Syria. Even though direct Ottoman rule was imposed by force, it was maintained by persuasion; in that sense Ottoman officials can be regarded as influential 'in advancing the objectives of the 
Ottoman state'. ${ }^{59}$ As a result, Hüseyin Hilmi Efendi was becoming more of an expert on crisis management, specializing particularly in regions where different local groups struggled against each other, as well as in places where the central government was trying to consolidate its rule through new enterprises.

On 13 March 1896, after nearly three years of service in Ma'an-Karak, Hüseyin Hilmi Efendi was appointed to the sancak of Nablus in, again, the recently established Ottoman province of Beirut. ${ }^{60}$ Nablus was also an Ottoman district that had relative autonomy, the capital of a mountainous region as well as being a commercial centre due to its manufacturing businesses. ${ }^{61}$ Hüseyin Hilmi's designation was not merely incidental; rather, it was the result of a personal undertaking on the part of the governor of Beirut, Nasuhi Bey. He had written to Yıldız Palace on 3 March 1896, expressing the need to replace the mutasarrif of Nablus, Cevdet Pasha, who had been unable to get along with the community of the region. The governor believed Hüseyin Hilmi, with his well-known sophistication and competence (vukûf ve kifâyeti müsellem), was a suitable candidate to implement the long-awaited implementation of administration (tanzîm-i idâre). ${ }^{62}$

However, Hüseyin Hilmi's appointment to Nablus seems to have remained on paper, since no evidence of his arrival in the city is available. Instead, he was soon appointed back to Karak as his superiors did not want to risk the stability achieved in the district and so insisted on not losing the architect of that order. ${ }^{63}$ Even though he was officially the mutasarrif of Karak from 27 April to 25 July 1896, numerous items of correspondence prove that Hüseyin Hilmi Efendi was reluctant to return to Karak, and in fact probably never did. He was either seriously ill or else stubbornly presented his physical condition as an excuse to remain, during the following year, in Beirut, where he had been living since he left Karak, most likely in March 1896. ${ }^{64}$ On 6 May 1896, as a result of his own personal request, Hüseyin Hilmi Efendi obtained a medical report confirming his health problems. A committee of doctors and sanitarians listed a number of the illnesses he suffered from, concluding their report as follows: 'with respect to the aforementioned conditions and illnesses, to employ the said person in a coastal place with mild weather is scientifically suitable'. ${ }^{65}$

An overview of Hüseyin Hilmi's career points to the importance of his years in Karak, as they provided him with solid experience in administering challenging regions and firmly integrated him into the body of the Hamidian provincial administration. In his annual report on Turkey in 1908, the British ambassador to the Porte, Sir Gerard Lowther, asserts that Hüseyin Hilmi Efendi was recognized by the sultan for the first time through his mutasarriflı to Karak; he succeeded at improving both the region and its people. ${ }^{66}$

Hüseyin Hilmi's final appointment to a mutasarrıflı was for the sancak of Süleymaniye in the province of Mosul. He was ordered to take up his new post immediately on 5 November $1896 ;{ }^{67}$ however, once again, he put forward health issues and submitted his resignation by the end of the same month. ${ }^{68}$ It is very likely that Hüseyin Hilmi Efendi spent the following six months in Beirut to recover. This is how this first stage of his career came to a close. Even so, Hüseyin Hilmi Efendi had accumulated a strong administrative repertoire in the empire's eastern provinces, and was soon to continue serving the sultan in the same region as his governor. 
Hüseyin Hilmi Efendi had been in the civil service for 23 years before he was finally promoted to the governorship of a province (vilâyet). In that time, he had repeatedly proved himself as an able and loyal servant of the sultan. Abdulhamit Kırmızı argues that, despite the fact that a modern education and graduation from the Mekteb-i Mülkiye (School of the Civil Service) had become increasingly important in appointments to high state positions under Abdülhamid II, this was not at all an indispensable criterion. Both governors and their deputies were often selected from among experienced statesmen, and especially from among those who were knowledgeable concerning local issues. ${ }^{69}$ This appears also to have been the case for Hüseyin Hilmi Efendi: though he was not a graduate of the modern schools, his success during his mutasarriflk paved the way for his rise and marked the beginning of his reputation. The governor of Syria, Rauf Pasha, was the patron who introduced him to Istanbul and, as Abdurrahman Şeref, puts it, 'he was then a nominee for governorship' (vâliliğe nâmzed). ${ }^{70}$

On 23 March 1897, Hüseyin Hilmi Efendi received an order from the Porte informing him of his appointment to Adana in place of Governor Faik Pasha. ${ }^{71}$ A resolution by the Special Council of Ministers (Encümen-i Mahsûs-ı Vükelâ) emphasized the need to replace Faik Pasha with a more able and powerful statesman, owing to the increasing 'importance and delicacy' of Adana Province. Among the candidate governors who were considered, Hüseyin Hilmi Efendi came to be preferred because he appeared to possess the required qualifications. The cabinet decision was approved by the palace and implemented on 23 March 1897. ${ }^{72}$ Hüseyin Hilmi Efendi was promoted to the rank of Rütbe-i Bâlâ and received the Mecidiye Order of the first degree in the same week. ${ }^{73}$ Upon this honour, the new governor expressed his sincere gratitude to the sultan in a private letter. ${ }^{74}$

The very first month of Hüseyin Hilmi's governorship coincided with the OttomanGreek War (25 April 1897-19 May 1897). However, the particular challenge that Hüseyin Hilmi faced was not a result of the ongoing conflict with the Greeks, but was rather related to the presence of rebellious Armenian subjects in Adana. Despite the fact that order was largely maintained in the province throughout the crises of $1894-96,{ }^{75}$ during which many eastern provinces witnessed bloodshed, Adana was still considered a sensitive province. This was a time of intensive European attention toward non-Muslim Ottomans, due not only to the recent Armenian crises, but also to the recurrent Cretan Question.

In addition to the routine duties of a governor, Hüseyin Hilmi Efendi had to deal with the Armenian subjects so as to maintain order in the province. One piece of evidence for this is that present among his personal papers there is a notebook consisting of the names of and information on the rebellious Armenians in the region. ${ }^{76}$ However, his period of service in Adana did not last long, as he was dismissed by the Council of Ministers on 17 November 1897. The reason for his dismissal from his first governorate was recorded as 'political reasons'. ${ }^{77}$

Ottoman officials detected that the agent of Austrian Lloyd Company in Mersin, Antuan Brazzafoli, was in fact a mediator between the Armenian committees within the empire and the committees abroad. When Governor Hüseyin Hilmi Efendi was informed concerning this subject, he wanted Brazzafoli to appear before the court. However, the Porte did not want the agent to face a trial; deportation seemed a less problematic solution, although the subsequent course of events would prove them wrong. $^{78}$ This minor 
incident was soon to evolve into a major diplomatic crisis between the Austrian Empire and the Ottomans. Austria demanded a formal apology, which included the dismissal of the governor of Adana as well as the mutasarrif of Mersin. ${ }^{79}$ Hüseyin Hilmi Efendi thus appears to have been the victim of a decision made by the central government, which he did not support from the beginning.

However, dismissing Hüseyin Hilmi was not a desired move by the Porte, but rather something they were compelled to do in order to avoid a further diplomatic crisis with the Western powers. The governor's administrative abilities and monitoring skills were clearly not in doubt, as his next post was just as challenging. Less than a month after his dismissal, he was charged with an inspection mission to the province of Basra, yet another Ottoman province which was the scene of regional conflicts. He was ordered to proceed to Basra, accompanied by an aide-de-camp of the sultan, ${ }^{80}$ and investigate the 'Qatar incident', as well as the issue of Mubarak Al-Sabah of Kuwait. ${ }^{81}$ Despite the fact that we have documentation concerning Hüseyin Hilmi's appointment, penned in a straightforward tone and ordering him to proceed to his new post immediately, a resolution by the Council of Ministers dated a few days later reveals that Hüseyin Hilmi Efendi again cited health problems as a reason not to proceed to the post. His request was granted and, in his stead, Hasan Pasha was appointed to Basra. ${ }^{82}$ The British consul in Baghdad reports that Hüseyin Hilmi Efendi was expected to arrive at Basra to enquire about the disputes between the governor of Basra and the commander of the Basra Flotilla over the affairs in Kuwait. ${ }^{83}$ However, there are no extant documents indicating that Hüseyin Hilmi ever embarked for Basra. On the contrary, it is highly unlikely that he did, since his next duty had begun by April 1898. But still, the Hamidian government's preference once again shows that Hüseyin Hilmi was considered an able servant to be trusted in difficult regions.

In April 1898, we see Hüseyin Hilmi Efendi appointed as the governor of Yemen, the south-easternmost province of the Ottoman Empire. His subsequent four years of service in Yemen is crucial for comprehension of his career path, which at this point was still on the rise. Based on the information provided by Abdurrahman Şeref, ${ }^{84}$ Süleyman Kani Irtem narrates the conditions under which Hüseyin Hilmi Efendi began his new duty:

While Abdülhamid was quite disturbed by the affairs in Yemen, Hüseyin Hilmi Efendi, who had been dismissed [from the governorship of Adana] due to complaints by the Austrian embassy, was present in Istanbul. Abdülhamid could not stand Imam Yahya, yet was unable to subdue him by military force. This is why he came up with the idea to handle the Yemenis through soft and gentle political measures. However, he could see no one among the ulama who could govern Yemen well. The Arab izzet Pasha recommended Hüseyin Hilmi Efendi, who had been the mutasarrif of Karak for four years and succeeded in implementing order in places where the government had never managed to achieve order before. Hüseyin Hilmi Efendi had received a madrasah education and always been successful in the posts he had held ... [So] Abdülhamid assumed he would be competent in implementing his visions concerning Yemen, and [Hüseyin Hilmi] was appointed to Yemen. ${ }^{85}$

Yemen was not a popular location among governor nominees. ${ }^{86}$ Appointment to distant regions automatically brought to mind the concept and practice of banishment by the palace (sürgün). However, the course of his career and his accumulated experience reveal that this was in fact a step forward for Hüseyin Hilmi. In his comprehensive study on Hüseyin Hilmi's governorship in Yemen, Yahya Yeșilyurt concludes that he was indeed a 
successful administrator, a fact which indicates that his appointment to this province was made solely due to his skills in provincial administration. ${ }^{87}$

At the close of the nineteenth century, Yemen was one of the empire's more fragile regions, with its problems having sectarian as well as socio-political roots. Yemen had a tribal structure, and the Zaidi sect, whose adherents did not recognize Ottoman religious authority, was widespread among its people. As a result, Yemen was often the scene of rebellions. Two major uprisings took place there in the years 1889 and 1895, with the first being suppressed by the Ottoman armies while the second, led by Imam Yahya, could not be entirely pacified. ${ }^{88}$ It was then that the idea of employing soft power against the Yemenis was put into practice by Sultan Abdülhamid.

By a decision of the Council of Ministers dated 20 April 1898, the governorship of Yemen was to be separated from the command of the regional army (Ordu-yu Hümâyûn Müşiriyeti) and Hüseyin Hilmi Efendi was to be appointed as the new governor. So as to establish order in the region, a reform committee was also to be sent to Yemen to work according to an ordinance. The council's resolution also acknowledged the lack of proper government in Yemen and touched upon issues of maladministration, such as offending and alienating Yemenis by engaging in corrupt practices and over taxation. The resolution also stated the necessity to prevent all abuses, to implement public order, to persuade the region's people by appointing a suitable governor, and to send a reform committee made up of able, honest and pious men. ${ }^{89}$ Not only was Hüseyin Hilmi Efendi mentioned by name, but the members of the committee were also determined at the outset. ${ }^{90}$ In this way, the Hamidian government initiated a reform scheme in Yemen, and Hüseyin Hilmi Efendi - soon to be granted the title of pasha - was chosen as the one to put the scheme into practice.

Hüseyin Hilmi's appointment to Yemen was, in a way, the only one of its kind. The new governor received special instructions regarding his clothing for his new duty. ${ }^{91}$ The sultan wanted the governor, as well as other officials in Yemen, to dress like ulama: they were to wear loose gowns and wrap a turban around their head in order to impress and win the sympathy of the locals. It is interesting that this clothing issue was the foremost matter to appear in every account concerning Hüseyin Hilmi's governorship in Yemen. Despite a certain degree of exaggeration, it still deserves some attention as a tool of soft power. The orders concerning clothing immediately started to show the desired impact on the routines of the provincial officials serving in Yemen..$^{92}$ It also had such minor consequences as the resignation of the mutasarrıf of Hodeida (Hudeyde), Rüşdi Pasha, who preferred to resign from his position rather than obey an order which he believed to be of no benefit. ${ }^{93}$ The clothing policy was never abandoned during Hüseyin Hilmi's period of service, and was even continued afterwards, during the governorship of Tevfik Pasha. ${ }^{94}$

As mentioned above, Hüseyin Hilmi Efendi and the reform committee were handed an ordinance when appointed to Yemen, instructing them with direct orders about the expected reforms. The instructions included the prevention of local abuses, the reassignment of all state officials, the implementation of law, investigation into the convenience of Yemeni codes, tax regulations, official rewards, the improvement of trade and agriculture, the construction of railways and educational institutions, and the organization of local security forces. ${ }^{95}$ Hüseyin Hilmi and the reform committee achieved improvements in numerous areas. There are records concerning Hüseyin Hilmi's taking measures to 
pacify rebels, dismissing corrupt officials, ${ }^{96}$ contributing to infrastructure, having government buildings constructed, establishing schools, and working on the local tax system. ${ }^{97}$

On 31 May 1899, after having served more than a year in Yemen, Hüseyin Hilmi Efendi was raised to the rank of vizierate, as well as being granted the exceptional privilege of preserving his manner of dress. ${ }^{98}$ Thus, from the age of 44 , he was allowed to use the title pasha, the highest obtainable title in Ottoman statehood: by the time of Abdülhamid II, pashas made up the majority of high Ottoman dignitaries. ${ }^{99}$ An army major from among the sultan's aides-de-camp, Es-Seyyid Ahmed, was employed to bring to Hüseyin Hilmi the imperial edict promoting him to the vizierate (Menşur-ı Âli). Upon his return, Es-Seyyid Ahmed wrote a detailed report on the pasha's achievements in the province. ${ }^{100}$ Immediately upon receiving his new rank, Hüseyin Hilmi Pasha expressed his gratitude to the sultan via a telegram addressed to the palace secretariat, which was penned in a highly panegyric tone and was full of lofty expressions. ${ }^{101}$

Hüseyin Hilmi Pasha was keen on ingratiating himself with the local inhabitants of Yemen; for instance, he made a donation of 24,000 riyals to the poor of San'a, as well as other donations to a number of other Yemeni cities. Moreover, he contributed to the region's educational system by establishing an administration for education, and he always relied upon the local ulama. ${ }^{102}$ The British military attaché Colonel J.G. Ponsonby reported to the Ambassador Nicholas O'Connor praising Hüseyin Hilmi Pasha for his honesty and capability, but he also said that 'too much was expected of him by way of instituting reforms and being sensitive to Yemeni viewpoints'. ${ }^{103}$

According to Süleyman Kani İrtem, Hüseyin Hilmi Pasha submitted a memorandum (layiha) to Abdülhamid, recommending that an autonomous administration be set up in Yemen. The revenues of the province were to be allocated to Yemeni public works. Abdülhamid, concerned about the possible outcomes, consulted his dignitaries and approved of Halil Rifat Pasha's advice to instruct Hüseyin Hilmi to preserve the status quo. ${ }^{104}$

Another significant consequence of Hüseyin Hilmi's service in Yemen - one related to his efforts to implement reforms in the region - was an assassination attempt that occurred on 6 June 1900. The reform committee had dismissed an illiterate kaimmakam, Ahmed Baban, who laid all the blame for his dismissal on the governor and shot him on the stairs in the governor's mansion. Hüseyin Hilmi Pasha survived his wound, however, and the assassin was immediately shot to death by the gendarmerie. ${ }^{105} \mathrm{~A}$ suicide note was found on the assassin's body, which would have significant implications for the subsequent career of Hüseyin Hilmi Pasha.

Everyone is aware that Hüseyin Hilmi Pasha was Namık Bey's servant (odacı). How did it happen that a man of such reputation was appointed with the rank of vizierate to a place with a population of some five million? That is astounding. It is a known fact that the governor is in cooperation with the committee in Europe and sends money to Young Turks. That is why this man should be killed... ${ }^{106}$

The investigation into the incident was carried out by the reform committee, and, after a series of inquiries, they came up with a list of co-conspirators and uncovered the course of events. ${ }^{107}$ At the head of those who had instigated the incident there appeared to be a man called Mustafa Şevket, who had previously made similar accusations concerning Hüseyin Hilmi Pasha in other places. The governor sued him for slander and sent him to Istanbul on 14 August $1900 .^{108}$ 
This incident is significant for this study in two ways. First, it proves that, with the existing local power groups reluctant to lose any influence they possessed, carrying out reforms in Yemen proved to be a difficult undertaking. Hüseyin Hilmi Pasha, as the direct implementer of those reforms, paid a very heavy personal price for his efforts. Second, this is an early example of Hüseyin Hilmi Pasha being accused of having relations with the Young Turks, something that was to remain a question mark about him till the very end of his career. Despite there being no solid answers in this regard as of yet, this is a crucial phenomenon to keep in mind regarding Hüseyin Hilmi's subsequent duty in Macedonia on the eve of the Young Turk Revolution in 1908.

Hüseyin Hilmi's final year in Yemen does not seem to have been a peaceful one for the pasha. The ongoing disputes between the commander of the army, Müşir Abdullah Pasha, and the governor were as clear as day. ${ }^{109}$ In April 1902, Hüseyin Hilmi received a warning from the government regarding his failure to deal with local matters. In his response, the pasha assumed a strangely humble attitude, accepting all the accusations. He concluded his telegram by suggesting he be replaced in Yemen by a governor whose ability had been proven, and asked that he be transferred to a 'negligible region' (gayr-i mühim mahâl). ${ }^{110}$ On 1 June 1902, he continued this attempt, sending a telegram to Yıldız Palace and asking to be deployed to Trablusgarb (Tripoli), Baghdad, Bitlis or Mamuretü'l-aziz. He asserted that, due to his health problems, it was impossible for him to continue in Yemen. $\mathrm{He}$ also felt the need to emphasize that he was neither seeking comfort nor escaping service; he would loyally serve anywhere upon the imperial consent. ${ }^{111}$

It was the ongoing dispute between the governor and the müşir that resulted in the former's decision to resign. As he was waiting for the approval of his resignation, he did not go to the governor's mansion, staying at his personal residence instead; as a result, his continuing in the post was deemed inappropriate. ${ }^{12}$ Hüseyin Hilmi Pasha was dismissed as governor of Yemen on 16 November 1902. ${ }^{113}$

Despite his success in his attempts to implement certain institutional and infrastructural reforms, Hüseyin Hilmi ultimately could not overcome Yemen's chronic problems; namely, those regarding tribal matters. As Farah puts it:

Hilmi was judged an excellent governor for Europe but unsuited to Yemen. He wanted to abolish the role shaykhs played as links between the government and tribes and replace them with Turkish officials. The shaykhs were prepared neither to lose their dignity nor be reduced to poverty. Their exasperation, not popular discontent, had led to revolt and, they claimed, no religious question was at stake. ${ }^{114}$

Governing Yemen while simultaneously attempting to implement reforms and struggle against various parties was indeed a difficult task. As such, his years in Yemen undoubtedly made a significant contribution to Hüseyin Hilmi's skill in crisis management. Hüseyin Hilmi Pasha's departure was lamented by the Yemenis due to the fact that 'he was one of the few governors who worked to improve the situation in the country'. ${ }^{115}$ On the other hand, the next post to which he would be appointed would show that the Hamidian regime was in fact not at all discontent with the pasha.

On 30 November 1902, Hüseyin Hilmi Pasha was appointed to the newly instituted General Inspectorate of Rumelia. ${ }^{116}$ It was a time when regional tendencies were at their peak and the Macedonian Question was going through a critical phase. The news provoked 
questions from contemporaries, one of which was by Fazlı Necip, quoted at the beginning of this essay. ${ }^{117}$ On the other hand, perhaps retrospectively, this political development does not seem to have been a great surprise to many, such as the British Consul-General in Salonica, Sir Robert Windham Graves, who noted the following in his personal memoirs:

Recognizing the dangers of such a situation, Sultan Abdul Hamid had appointed as his representative in Macedonia one of his most able servants, Hilmi Pasha, with the title of InspectorGeneral of the Three Vilayets, namely Salonica, Monastir and Uskub, the Governors-General of which had been placed under his orders. ${ }^{118}$

The job definition of the inspectorate, though having wider authority and power, nevertheless had much in common with Hüseyin Hilmi Pasha's recent governorship in Yemen. For instance, both duties began with a reform scheme and sultanic ordinances, and in both cases Hüseyin Hilmi Pasha had a group of able and experienced officials to assist him with the implementation of the reforms. At the same time, these two regions of the empire were disparate in terms of geographic conditions and socio-cultural structures: Rumelia was at roughly the western end of the Ottoman lands, whereas Yemen was the southernmost edge, and their populations consisted of entirely different groups of Ottoman subjects. However, in both cases, the local tribes, communities or parties not only had problems with the Ottoman government, but were also in armed conflict with one another.

In addition to his regional administrative commitments, Hüseyin Hilmi Pasha also possessed diplomatic responsibilities. Yemen and Ottoman Macedonia were regions that attracted foreign attention due to their strategic locations. Foreign powers interfered in local internal affairs, and so Hüseyin Hilmi had to compete with both elements without causing diplomatic crises while also protecting the rights and interests of the Ottoman government insofar as he was the highest imperial representative in the region.

Until he became the Minister of the Interior in November 1908, after the Young Turk Revolution, Hüseyin Hilmi Pasha served as the inspector general uninterruptedly for more than six years. The details of his inspectorship are beyond the scope of this study. It is, however, reasonable to state that his success was generally admitted by his contemporaries. On several occasions he was retained in the same position much longer than would have been anticipated. Moreover, it is crucial to be aware of the fact that he also managed to retain his title on the eve of the Second Constitutional Period, as well as during that period's early days.

Hüseyin Hilmi Pasha was a prominent Hamidian statesman. He proved himself an able servant in several places and on multiple occasions. Taking into account how much Sultan Abdülhamid II invested in his centralization policies, the selection of Hüseyin Hilmi for particularly fragile regions cannot be mere coincidence: his loyalty was not in doubt. After all, even if Hüseyin Hilmi's suspected 'Young Turk connection'119 was a reality, it did not make him any less of a Hamidian servant. Feroz Ahmad challenges inal on his assertion that 'Hilmi Pasha's career suffered because of his modest background and education', making a very accurate observation: 'the evidence hardly bears this out; he rose to high positions under both the Palace and the constitutional regimes'. ${ }^{120}$ It appears that Hüseyin Hilmi Pasha was on good terms with the Young Turks, as he refrained from struggling against them in Macedonia on the eve of the Second Constitutional Period, and later became grand vizier as well. Moreover, it would not be a crucial mistake to deem Hüseyin 
Hilmi a pro-constitutionalist, as he was a disciple and admirer of Namık Kemal, the predecessor of the Young Turk generation and the forerunner and champion of constitutional monarchy in the Ottoman Empire.

A closer analysis of Hüseyin Hilmi Pasha's bureaucratic career displays that the Fazlı Necip's basic question - why was Hüseyin Hilmi Pasha appointed inspector general of Rumelia? - was not a difficult one to respond to, and the answer was quite coherent within itself. First of all, Hüseyin Hilmi Pasha's early years in the civil service were very much aided by Namık Kemal's support, and subsequently followed by the patronage of Naşid Pasha. He consolidated his rise to higher positions through classical methods. As he patiently rose through the ranks in his bureaucratic career, he did not refrain from making whatever moves were necessary for advancement, whether it be writing florid letters of thanks to his superiors, including the sultan himself, or asking to be excused from an appointment for health issues, which usually seem to have been only nominal excuses used to achieve a better post. Moreover, beginning with his very first appointment to the mutasarrıflk of Mersin, Hüseyin Hilmi Pasha's career path appears to have followed a pattern that allowed him to specialize in crisis management and the implementation of administrative and institutional reforms in regions having similar local problems. Hüseyin Hilmi Pasha did not serve in Rumelia before his appointment to this high level position, ${ }^{121}$ but he did possess all the qualifications and experience necessary for the inspectorate. On the other hand, as mentioned above, Hüseyin Hilmi Pasha was to reach even higher state positions in the near future; however, with the marks that his time as inspector general left in the final decades of the empire, it is significant to trace all of his footsteps - from a young clerk from Midilli all the way to the general inspectorate of Rumelia. Hüseyin Hilmi Pasha's rise reveals the logic and methods behind the Hamidian administration in terms of supporting the specialization of its statesmen and dealing with particularly complicated regions, especially during times of crisis.

\section{Disclosure statement}

No potential conflict of interest was reported by the author.

\section{Notes}

1. Prime Minister's Ottoman Archives (Hereafter BOA) Y. A. RES. 118-82 (16 Teşrinisani 1318/29 November 1902); Güler Yarcı, 'Osmanlı Diplomasisinde Makedonya Meselesi (1876-1912)' (PhD Thesis, Marmara University, 1996), p.163.

2. 'Biz Makedonyalılar, bütün bu ahvali asabi bir heyecan ile takip ediyorduk. İstanbul gazeteleri bu meseleden bahsedemiyorlardı. Fakat, teşebbüsler tafsilatıyla yabancı gazetelerinden haber alınıyor, Makedonya'nın her tarafında duyuluyordu. İşte bu sırada bir gün Rumeli Vilayetleri Umumi Müfettişliğine Hüseyin Hilmi Paşanın tayin olunduğunu haber aldık. -Bu Hüseyin Paşa kim? birbirimizden soruyorduk. Kendisi meşhur ricalden değildi. Rumeli'de hiç bulunmamıştı. Şimdi koskoca Rumeli'yi bir nevi prens gibi yarı istiklal ile idare edecek olan bu müfettişin halinin hususiyetini anlamak için her yerde günlerce bundan bahsedildi'. Fazlı Necip, 'Makedonya'da son günlerimiz ve Umumi Müfettiş Hüseyin Hilmi Paşa', Yakın Tarihimiz, Vol. IV (Istanbul: Türk Petrol, 1962), p.362.

3. This document is incomplete; it looks as if it was begun by Hilmi Pasha and then either could not be completed or else the sequel has been lost. İslam Araştırmaları Merkezi Hüseyin Hilmi Paşa Evrakı (Hereafter iSAM-HHP) 1-20 (16 Şubat 1318/29 January 1903). 
4. iSAM-HHP 22-1412 (29 Cemazielahir 1299/18 May 1882).

5. 'Efendi: ... (5)Title used by the Scribes and secretaries of the Ottoman civil service', Selcuk Aksin Somel, $A$ to $Z$ of the Ottoman Empire, (Plymouth: The Scarecrow Press, 2010), p.82.

6. Hüseyin Hilmi Pasha's Sicill-i Ahval Record, BOA. DH. SAID. 25-90. This document is the main chronological scheme that this study takes as its base. For a detailed description and evaluation of the Sicill-i Ahval records, see. Olivier Bouquet, Sultanın Paşaları (1839-1909), (Istanbul: Işs Bankası Kültür Yayınları, 2016), pp.55-119.

7. Namık Kemal was a prominent member of the Young Ottomans during the reign of Sultan Abdülaziz. He was known for his liberal ideas and was also a member of the committee that prepared the Kanun-I Esasi. He was later exiled by Abdülhamid II, along with the other Young Ottomans.

8. Ali Ekrem Bolayır, Namık Kemal, (Istanbul: Devlet Matbaası, 1930), p.52; Ömer Faruk Akün, 'Nâmık Kemal', İslam Ansiklopedisi, Vol.32, (Istanbul: Türkiye Diyanet Vakfı, 2006), p.370.

9. 'Mutasarrif': The governor of a sanjak of which several form a vilayet, under a governor general or Vali', Sir James W. Redhouse, 'Mutasarrif', Turkish and English Lexicon, 1890, p.1704.

10. BOA. DH. SAID. 25-90.

11. A number of Namık Kemal's personal letters were actually written down by Hüseyin Hilmi. Namık Kemal referred to Hüseyin Himi as his clerk. See: Fevziye Abdullah Tansel, Namık KemaI'in Mektupları III (Ankara: Türk Tarih Kurumu Basımevi, 1973), p.140 and passim.

12. Ibid. II, III and IV, passim.

13. Ali Akyıldız-Azmi Özcan, Namık Kemal'den Mektup Var (Istanbul: Türkiye İş Bankası Yayınları, 2013).

14. Akyıldız-Özcan, p. XLIV, [44]; Intisab can be defined as 'being or becoming attached to the household of a grandee' in Lexicon, Sir James W. Redhouse, p.209. In the Ottoman tradition, it was very common for bureaucrats to raise young and promising men for state service by their side, even literally within their household. This method provided the master with able and loyal companions and the young men with proper training and a chance for a better future. For further reading see: A.H. Dursun, '19. Yüzyılda Adam Yetiştirmede Hânegîi-Himâye Usûlü', Kubbealtı Akademi Mecmuası, No.100 (1996), p.78.

15. Letter dated 16 Mayıs 1298/28 May 1882, iSAM-HHP 832 in Akyıldız-Özcan, p.47.

16. BOA. DH. SAID. 25-90; iSAM-HHP 14-913 (26 Kanunusani 1299/7 February 1884).

17. Martin Strohmeier, 'Mehmed Tevfik Bey, Companion and Collaborator of Namık Kemal During His Years in the Aegean Province', Archivum Ottomancium, No.23 (2005/06), p.272.

18. Letter dated 11 Cemazielahir 1296/2 June 1879 in F. A. Tansel, Namık Kemal'in Mektupları II (Ankara: Türk Tarih Kurumu Basımevi, 1969), p.431.

19. Letter dated 13 Kanunuevvel 1297/25 July 1881 in Tansel III, pp.110-111; lbid., p.273

20. 'Midilli Tahrirat Müdüriyeti'nde bulunan Hüseyin Hilmi Efendi bendeleri mebâdi-i memuriyet-i bendeganemden beri ahlakça evliya-yı umur hazeratının sahihen takdirine şâyân olacak kadar istikamet, marifet ve iktidarca Midilli'de yetişmiș bir memurdan hemen hiçbir vakit memul olunacamayacak derecelerde kifayet göstermiş olduğundan ve vilayât-ı hazret-i padişahîde o meziyet-i irfanı haiz belki bir iki mektupçu bulunamayacağından memuriyetçe daha mebâdi-i neş'ette bulunan ve yetiştiği hâlde devlete gerçekten hizmet edeceği nezd-i çakeranamede bilfiil sâbit olan mûmâ-ileyh bendelerinin bir mektupçuluğa tayinini suret-i mahsusada istirham eder ve ahlâk ve iktidarı hakkındaki şehadet-i kemteranemin nâiliyetiyle müftehir olduğum teveccühat-ı celile-i rahîmaneleri iktizasınca nezd-i sâmî-i dâver afhamilerinde mazhar-ı hüsn-i kabul olacağına itimad eylerim.' Letter dated 7 Mayıs 1299/19 May 1883 from Sinan Kuneralp Collection in Akyıldız-Özcan, pp.64-5.

21. Letter dated 2 Temmuz 1299/14 July 1883, from Sinan Kuneralp Collection in Akyıldız-Özcan, pp.77-8.

22. 'Memûriyetini mukaddime-i ikbâl olmak şartıyla tebrik ederim' iSAM-HHP 13/843 (30 Temmuz 1299/7 August 1883); also see: iSAM-HHP 14 / 913 (26 Kânunusânî 1299/7 February 1884), iSAM-HHP- 23/1506 (23 Ağustos 1301/4 September 1885).

23. Reşat Kasaba, 'İzmir', in Ç. Keyder, Y.E. Özveren, D. Quataert (eds.), Doğu Akdeniz'de Liman Kentleri 1800-1914 (Istanbul: Tarih Vakfı Yurt Yayınları, 1994), pp.1-22. 
24. Raif Nezihi, İzmir'in Tarihi, E. Üyepazarcı (ed.), (İzmir: İzmir Büyükşehir Belediyesi Kültür Yayınları, 2001), p.4.

25. Hüseyin Hilmi Effendi's Sicill-i Ahval record as Hüseyin Hilmi Paşa'nın Syria Vilâyeti MektupçusuiSAM-HHP 22 /1413 (15 Kânunusanî 1304/27 January 1889).

26. Abdülhamid II ascended to the throne in September 1876, and his early reign was occupied with the 1877-78 Russo-Ottoman War, the first trial of the constitutional monarchy in the empire and the power struggle between the Sublime Porte and the palace. By the early 1880s, Abdülhamid 'overcame' these obstacles and began to consolidate his absolute rule.

27. Letters dated 8 Mart 1300/20 March 1884 and 16 Mart 1300/28 March 1884 from iSAM-HHP collection in Akyıldız-Özcan, p.143,147.

28. Letter dated 4 Eylül 1301/16 September 1885 from ISAM-HHP Collection in Akyıldız-Özcan, p.209.

29. 'Beyrut gibi mühim bir mutasarrıflı̆̆a tayini mukaddema Naşid Paşa tarafından dahi arz ve inha edilen Suriye mektubi-i esbakı Saadetlü Hüseyin Hilmi Efendi ...' BOA. Y. MTV. 73-137 (20 Cemazieahir 1310/9 January 1893.

30. BOA. DH. SAID. 25-90.

31. The following letter from Namık Kemal is dated 1 November 1885 , and suggests that Hüseyin Hilmi refrain from changing offices (memuriyet tebdili) since the grand vizierate was held by Kamil Pasha at the time, and it would be better to wait for Said Pasha to regain this post. Letter dated 20 Teșrinievvel 1301/1 November 1885 from iSAM-HHP Collection in Akyıldız-Özcan, pp.211-12.

32. BOA. DH. MKT. 1445-108 (22 Zilhicce 1304/10 September 1887).

33. BOA. DH. SAID. 25-90.

34. Ibid.; Mektubi Hüseyin Hilmi Effendi received the Order of the Crown of Italy of the second degree along with the mutasarrif of Beirut, Nasuhi Bey, and the deputy governor Eşref Pasha, due to their hospitality during the visit of the Italian crown prince to the province of Syria when he was on his way to Jerusalem in early 1887. BOA. I. DH.1036/81512 (7 Ramazan 1304/ 30 May 1887). A letter in Italian, written from the Italian Ministry of Foreign Affairs in Rome, was addressed to 'Hüseyin Hilmi Effendi' and is present among his papers: 'I am happy to announce to your excellency that his majesty the king, my august sovereign, has favored to give you, upon my proposal, the Order of the Crown of Italy, which is the level of great officials.' ISAM-HHP 20/1374 (14 April 1887).

35. BOA. i. DH. 1073-84179 (11 Recep 1305/24 March 1888).

36. Letter dated 31 Teşrinisâni 1304/25 November 1888 from Turkish Historical Society Namık Kemal Papers in Akyıldız-Özcan, Appendix I. pp.251-2.

37. F.A. Tansel, Namık Kemal'in Mektupları IV (Ankara: Türk Tarih Kurumu Basımevi, 1986), p.602.

38. BOA. DH. SAID. 25-90.

39. ISAM-HHP 22/1424 (8 Nisan 1308/17 April 1892).

40. ISAM-HHP 22/1422 (18 Nisan 1308/27 April 1892).

41. 'Bir hayli tebaası bulunduğu için umur-ı ecnebiyesi de suret-i mahsusada şayan-ı dikkat olan Mersin Sancağı mutasarrıflığında sadakat ve dirayetiyle beraber lisan ve muamelat-ı ecnebiyeye vakıf ve gayet müteyakkız bir bendenin istihdamına mütevafık olduğundan el-yevm mutasarrıflıkda bulunan Fehim Paşa'nın diğer bir mahal-i münasibe kaldırılarak yerine kifayet ve sadakati ve umur-ı ecnebiyede malumat ve tecarib-i kafiye ile elsine-i müteaddideye vukufu malum olan ve Beyrut gibi mühim bir mutasarrıflı̆̆a tayini mukaddema Naşid Paşa tarafından dahi arz ve inha edilen Suriye mektubi-i esbakı Saadetlü Hüseyin Hilmi Efendi Hazretlerinin tayini hakkında istida-i müsaade-i seniyye-i cenab-ı mülükaneye mücaseret olunduğu...' BOA.Y. MTV. 73-137 (20 Cemazielahir 1310/9 January 1893).

42. BOA. i. DH. 1301/24 (22 Cemazielevvel 1310/12 December 1892).

43. Ma'an is located in today's Transjordan. ISAM-HHP 23-1531, (1 Mart 1309/13 March 1893).

44. Engin Deniz Akarlı, 'Establishment of the Maan-Karak Mutasarrifiyya, 1891-1894' Dirasat, Vol.13 (1896), No.1, p.28.

45. Eugene L. Rogan, Frontiers of the State in the Late Ottoman Empire, (Cambridge: Cambridge University Press, 1999), p.52. 
46. Mustafa L. Bilge, 'Maan', İslam Ansiklopedisi, Vol.27, (Istanbul: Türkiye Diyanet Vakfı, 2003), p.270.

47. A. Latif Armağan, 'XVIII. Yüzyılda Hac Yolu Güzergahı ve Menziller', The Journal of Ottoman Studies, No. 20 (2000), p.94.

48. Akarlı, pp.28-9; Rogan, p.52.

49. BOA. BEO. 168-12532 (27 Şubat 1308/11 March 1893).

50. Akarlı, p.32-3.

51. ISAM-HHP 23/1531 (1 Mart 1309/13 March 1893).

52. Rogan, p. 54-5.

53. ISAM-HHP 11/653 ( 9 Teșrinievvel 1309/21 October 1893).

54. ISAM-HHP 11/635 (29 Cemazielevvel 1313/17 November 1895); isAM-HHP 11/652 (27 Cemazielevvel 1313/15 November 1895).

55. iSAM-HHP 20/1345 (28 Şubat 1309/12 March 1894).

56. iSAM-HHP 11/683 (5 Kânunuevvel 1309/17 December 1893).

57. ISAM-HHP 11/654 (15 Receb 1311/22 January 1894).

58. ' '... dört seneye karib bir zaman mezkur livada (maan) kalmış ve Hükümet-i Seniyyenin hakkıyla tesis edemediği o yerleri teşkilat-ı muntazama dairesine ve kavanin-i mevzua tahtına almağa muvaffak olmuşdur .' Abdurrahman Şeref, 'Viyana Sefir-i Sabık Hüseyin Hilmi Paşa', Tarih-i Osmani Encümeni Mecmuası, No. 49 (1325), p.65.

59. Rogan, p.55.

60. BOA. Y. MTV. 137-105 (18 Ramazan 1313/3 March 1896).

61. Beshara Doumani, Rediscovering Palestine: merchants and peasants in Jabal Nablus, 1700-1900, (California: University of California Press, 1995), p.1-2.

62. BOA. Y. MTV. 137-105 (18 Ramazan 1313/3 March 1896).

63. BOA. BEO. 776-58138 (23 Zilkade 1313/6 May 1896).

64. ISAM-HHP 20/1339 (22 Nisan 1312/4 May 1896); iSAM-HHP 13/804 (24 Nisan 1312/6 May 1896); iSAM-HHP 13/810 (25 Nisan 1312/7 May 1896).

65. 'Zikrolunan ahvâl ve avârıza nazaran müşarunileyhin havası mu'tedil ve sahil mahallerden birinde bir müddet istihdamı muvâfık-ı fen olduğunu mübeyyin rapordur' iSAM-HHP 13/806 (24 Nisan 1312/6 May 1896).

66. Halil Ersin Avcl, Türkiye 1908: Ingiliz büyükelçisi Sir Gerard Lowther'in 1908 yılı Türkiye Raporu, (Çanakkale: Çanakkale Onsekiz Mart Univeristy, 2003) p.31.

67. BOA. BEO. 863/64663 (29 Cemazielahir 1314/5 December 1896).

68. BOA. BEO. 874/65519 (24 Cemazielevvel 1314/31 October 1896).

69. Abdulhamit Kırmızı, Abdülhamid'in Valileri (Istanbul: Klasik Yayınları, 2007), p.46.

70. Abdurrahman Şeref, p.65.

71. BOA. BEO. $924 / 69296$ (19 Şevval 1314/23 March 1897).

72. BOA. I.DH. 1344/45 (19 Şevval 1314/23 March 1897).

73. BOA. DH. SAID. 25-90.

74. ISAM-HHP 10/98 (no date); HHP 20-1334 (21 Şevval 1314/25 March 1897).

75. Cemal Paşa, Hatıralar (Istanbul: Türkiye Işs Bankası Kültür Yayınları, 2001), p.393; Tetsuya Sahara, What Happened in Adana in April 1909?, (Istanbul: Isis Press, 2013), p.54.

76. iSAM-HHP 11-668 (7 Mart 1897/16 May 1897).

77. 'Müşarileyhin görülen lüzum-ı siyasiyye mebni azli Meclis-i Mahsusu Vükela kararıyla lede'l-arz makrun-ı müsâ'ade-i seniyye-i cenab-ı padişahi olmağla 1315 senesi Cemazielahiresinin 21'inde (5 Teșrinisani sene 313) infisal eylemişdir.' DH. SAID. 25-90.

78. IIlhan Ekinci, 'Ermeni Meselesinin Uluslararası Boyutuna Bir Örnek Brazzafoli Meselesi', Ermeni Araştırmaları, No.18 (2005), p.89-94.

79. According to Inal, an official apology was demanded from the governor Hüseyin Hilmi, who refused to provide one and was therefore dismissed. İbnülemin Mahmud Kemal İnal, Son Sadrıazamlar, XI.-XIV. Fascicle, (Istanbul: İş Bankası Kültür Yayınları, 2013), p.1658.

80. BOA. i. HUS. 59/1315 (18 Recep 1315/13 December 1897).

81. BOA. BEO. 1053/7893 (20 Recep 1315/15 December 1897); BOA. BEO. 1054/79027 (23 Recep 1315/18 December 1897).

82. BOA. Y. A. RES. 90/56. (24 Recep 1315/19 December 1897). 
83. Gökhan Çetinsaya, Ottoman Administration of Iraq (London: Routledge, 2006), p.68.

84. Abdurrahman Şeref, pp.65-6.

85. 'Yemen işleri Abdülhamid'i pek rahatsız ettiği sırada Hüseyin Hilmi Efendi Avusturya sefaretinin şikayeti üzerine [Adana valiliğinden] mazulen i̇stanbul'da bulunuyordu. Abdülhamid İmam Yahya'yı çekemiyor, asker kuvvetiyle hakkından da gelemiyordu. Bunun için bir kere de yumuşak ve tatlı siyasi tedbirlerle Yemenlileri elde etmek suretini düşündü. Fakat ulema içinden Yemen'i iyi idare edecek kimseyi göremedi. Arap İzzet Paşa Kerek Mutasarrıflı̆ında dört sene bulunarak geçen devirlerde hükümetin hakkıyla teessüs edemediği o yerleri nizam altına almağa muvaffak olmuş bulunan Hüseyin Hilmi Efendi'yi tavsiye etti. Hüseyin Hilmi Efendi vaktiyle medreseye devam etmişti; bulunduğu mansablarda işgüzarlık göstermiş, hüsnü sülûkiyle maruf olmuştu. Abdülhamid de nu Yemen hakkında tasavvurlarını icraya ehil addetti; Yemen valiliğine nasbedildi (29 Zilkade 1315).' Süleyman Kani İrtem, Osmanlı Devleti'nin Mısır Yemen Hicaz Meselesi,Osman Selim Kocahanoğlu (Ed.) (Istanbul: Temel Yayınları, 1999), p.145.

86. 'Did governors prefer some provinces appointments to others? The more distant provinces were more disliked by the nominees for governor. Yemen was the most disfavoured place, not just due to the distance, but also because of the domestic rebellions led by Imam Yahya, the incursions of British and then Italian forces in the south and Red Sea, and the smuggling of weapons into the highlands via powerful and defiant tribes.' Abdulhamid Kırmızı, 'Rulers of the Provincial Empire: Ottoman Governors and the Administration of Provinces, 1895-1908' (PhD Thesis, Boğaziçi University, 2005), p.62.

87. Yahya Yeşilyurt, 'Hüseyin Hilmi Paşa'nın Yemen Valiliği ve Ona Yapılan Suikast', OTAM, No.34 (2013), pp.280-1.

88. Ibid., pp.259-60.

89. BOA. Y. A. RES $92-50$ (3-1) (28 Zilkade 1315/20 April 1898).

90. BOA. BEO. 1123- 84202 (30 Zilkade 1315/22 April 1898).

91. BOA. Y. A. RES 92-50 (3-1) (28 Zilkade 1315/20 April 1898); BOA. BEO. 1123-84202 (30 Zilkade 1315/22 April 1898)

92. 'On the day that the new governor arrived, most of the provincial officials put on their ulama attire. Some of those who could not obtain robes wore cloaks; a very few appeared in frock coats. They all wrapped white thin fabric around their fez. It was in this bizarre ulama attire that the governor and his officials performed their first Friday prayer in the great mosque of Sana.' 'Yeni vali gelince bir günde vilayet memurlarının çoğu ulema kıyafetine girmişlerdi! Cübbe tedarik edemeyenlerden bir kısmı maşlah giymişlerdi; pek azı redingot ile görünmüştü. Hepsi feslerine bulabildikleri beyaz ince kumaşları sarmıştı. Vali ve memurlar bu garip ulema kıyafetiyle ilk cuma namazını Sana'nın büyük camiinde kıldılar.' ìrtem, p.146.

93. ibnülemin, p.1660.

94. The 'reputation' of Hüseyin Hilmi Pasha's Yemeni outfit was so widespread at the time that, even when he was appointed to Rumelia as the inspector general, it was still being talked about. The journalist Fazlı Necip visited the pasha on his arrival in Salonika and wrote that he pictured Hüseyin Hilmi Pasha in his Yemeni outfit and was surprised to see him wearing a monocle and dressed in quite a chic fashion. Fazlı Necip, p.362.

95. Yeşilyurt, pp.262-3.

96. Hüseyin Hilmi Pasha put the aide-de-camp of the former governor in jail, along with other officials who had abused their authority and oppressed the Yemeni people. Casear E. Farah, The Sultan's Yemen: 19th-Century Challenges to Ottoman Rule (London: I.B. Tauris, 2002), p.179.

97. Yeşilyurt, p.266-70.

98. Abdurrahman Şeref, p.66; 20 Muharrem $1317 / 31$ May 1899 is the date of vizirate according to his Sicill-i Ahval Record. BOA. DH. SAID. 25-90.

99. Olivier Bouquet, p.XIX, XXII.

100. BOA. Y. PRK. MYD. 23-23(29 Zilhicce 1317/30 April 1900).

101. BOA. Y. PRK. UM. 46-50 (22 Muharrem 1317/2 June 1899).

102. Farah, p.179.

103. Ibid., p.188. 
104. Farah also mentions a memorandum: 'Hilmi submitted a memorandum to the government outlining ways to improve the situation in Yemen and to avoid the excessive cost of constantly having to suppress rebellions caused by misadministration of self-serving officials. Justice could only be served, he argued, with decrees that were derived from the Shariah and strictly implemented. Taxes should be equitably levied and collected, but not by military officers using force. To increase revenue, the state should promote trade and economic growth, secure roads, build more technical, trade and craft schools and recruit Yemenis for police duty to lessen resistance.' Ibid., p.251; irtem, pp.148-9.

105. BOA. Y. EE. 65-21; 65-22 (24 Mayıs 1316/6 June 1900).

106. Yeşilyurt, p.275.

107. Ibid., pp.275-6.

108. BOA. Y. MTV. 205-98 (1 Ağustos 1316/14 August 1900).

109. For one of the many pieces of evidence relating to such controversies, see Hüseyin Hilmi's telegram to the palace, which features claims of the personal sacrifices he had made in order to get along with the commander, as well as certain complaints. BOA. Y. EE. 10-16 (4 Kanunusani 1314/16 January 1899); for Sadaret's warning see iSAM-HHP 16-1029 (20 Mayıs 1315/1 June 1899).

110. BOA. DH. MKT. 487-42 (8 Nisan 1318/21 April 1902).

111. 'Haşa hizmetten kaçınmak ve rahatımı aramak gibi şiar-ı diyanet ve sadakate münafi hal vallahi ve billahi hatır-ı çakeranemden bile geçmeyerek her nerede bulunsam velinimet-i bi-minnet-i azim efendimize sıdk u sadakatle hizmet ederek rıza-yı hümayun-ı cenab-ı hilafetpenahilerini bir kat daha istihsale mazhariyet aksa-yi makasıd-ı abidanemden olmağla Trablusgarb, Bağdad, Bitlis, Mamuretü'l-aziz vilayetlerine veya hangi mahal ve hizmete ferman buyurulur ise oraya naklimle yeniden ihya buyurulmaklığımı hak-i pay-i akdes-i hilafetpenahilerine yüzümü gözümü sürerek ve ağlayarak min gayr-i haddim arz ve istirhama cüret eylediğim maruzdur' BOA. Y. PRK. UM. 54-20 (13 Safer 1319/1 June 1901)

112. İbnülemin, p.1661.

113. BOA. DH. SAID. 25-90.

114. Farah, p.235.

115. Ibid., p.181.

116. BOA. DH. SAID 25-90.

117. Fazlı Necip, p.362.

118. Robert Graves, R. Storm Centres of the Near East (London: Hutchinson \& Co.,1933), p.196.

119. BOA. Y. MTV. 205-98. (1 Ağustos 1316/14 August 1900).

120. Feroz Ahmad, 'Husayn Hilmi Pasha', Encyclopedia of Islam (EI2), Vol.3 (Leiden: Brill, 1971), p.624.

121. See Figure 1 for a map of Hüseyin Hilmi Pasha's career up to the inspectorate. 